\title{
Type 3 Deiodinase, a Thyroid-Hormone-Inactivating Enzyme, Controls Survival and Maturation of Cone Photoreceptors
}

\author{
Lily Ng, ${ }^{1}$ Arkady Lyubarsky, ${ }^{2}$ Sergei S. Nikonov, ${ }^{2}$ Michelle Ma, ${ }^{1}$ Maya Srinivas, ${ }^{3}$ Benjamin Kefas, ${ }^{1}$ \\ Donald L. St. Germain, ${ }^{4}$ Arturo Hernandez, ${ }^{4}$ Edward N. Pugh Jr, ${ }^{2}$ and Douglas Forrest ${ }^{1}$ \\ ${ }^{1}$ National Institutes of Health, National Institute of Diabetes and Digestive and Kidney Diseases, Clinical Endocrinology Branch, Bethesda, Maryland 20892-1772, \\ ${ }^{2}$ Department of Ophthalmology, School of Medicine, University of Pennsylvania, Philadelphia, Pennsylvania 19104, ${ }^{3}$ Department of Human Genetics, Mount Sinai \\ School of Medicine, New York, New York 10029, and ${ }^{4}$ Department of Physiology, Dartmouth Medical School, Lebanon, New Hampshire 03766
}

\begin{abstract}
Maturation of the mammalian nervous system requires adequate provision of thyroid hormone and mechanisms that enhance tissue responses to the hormone. Here, we report that the development of cones, the photoreceptors for daylight and color vision, requires protection from thyroid hormone by type 3 deiodinase, a thyroid hormone-inactivating enzyme. Type 3 deiodinase, encoded by Dio3, is expressed in the immature mouse retina. In Dio $3^{-/-}$mice, $\sim 80 \%$ of cones are lost through neonatal cell death. Cones that express opsin photopigments for response to both short $(\mathrm{S})$ and medium-long $(\mathrm{M})$ wavelength light are lost. Rod photoreceptors, which mediate dim light vision, remain essentially intact. Excessive thyroid hormone in wild-type pups also eliminates cones. Cone loss is mediated by cone-specific thyroid hormone receptor $\beta 2(\mathrm{TR} \beta 2)$ as deletion of TR $\beta 2$ rescues cones in Dio3 ${ }^{-1-}$ mice. However, rescued cones respond to short but not longer wavelength light because TR $\beta 2$ under moderate hormonal stimulation normally induces $\mathrm{M}$ opsin and controls the patterning of $\mathrm{M}$ and $\mathrm{S}$ opsins over the retina. The results suggest that type 3 deiodinase limits hormonal exposure of the cone to levels that safeguard both cone survival and the patterning of opsins that is required for cone function.
\end{abstract}

\section{Introduction}

Thyroid hormone is critical for maturation of the mammalian nervous system. Conditions that impair thyroid hormone availability present risks to neurological development and include congenital hypothyroidism, which occurs in 1 in $\sim 3000$ human newborns (Rovet and Daneman, 2003), iodine deficiency (Cao et al., 1994), and insufficiency of maternal thyroid hormone during pregnancy (Morreale de Escobar et al., 2004). Neurodevelopment requires rising levels of circulating thyroid hormone at fetal and postnatal stages and, as shown recently, additional means that enhance specific responses to the hormone. Type 2 deiodinase, encoded by the Dio2 gene, provides one such mechanism by amplifying local tissue levels of triiodothyronine (T3) the main active form of hormone that binds the thyroid hormone receptor. Type 2 deiodinase generates T3 by outer ring deiodination of thyroxine (T4), the most abundant form of thyroid hormone in the circulation (Kaplan and Yaskoski, 1981; Bianco et al., 2002; St Germain et al., 2005). Dio2 $2^{-/-}$mice exhibit deafness and behavioral changes, indicating the importance of amplification of T3

Received 0ct. 23, 2009; revised Dec. 11, 2009; accepted Jan. 12, 2010.

This work was supported in part by the intramural research program at National Institutes of Health (NIH)/ National Institute of Diabetes and Digestive and Kidney Diseases, a Hirshl Award (D.F.), and NIH Grants HD09020, DK42271 (D.L.S.), and EY02660 (E.N.P.). We thank V. A. Galton for advice on this study.

Correspondence should be addressed to Douglas Forrest, National Institutes of Health, National Institute of Diabetes and Digestive and Kidney Diseases, Clinical Endocrinology Branch, 10 Center Drive, Bethesda, MD 208921772. E-mail: forrestd@niddk.nih.gov.

DOI:10.1523/JNEUROSCI.5267-09.2010

Copyright $\odot 2010$ the authors $\quad 0270-6474 / 10 / 303347-11 \$ 15.00 / 0$ levels within the nervous system (Ng et al., 2004; Galton et al., 2007).

Type 3 deiodinase, a thyroid hormone-inactivating enzyme, depletes sources of active hormone by inner ring deiodination of both T4 and T3. A developmental role has been shown for type 3 deiodinase in tail regression and asymmetrical eye growth during amphibian metamorphosis (Becker et al., 1997; Marsh-Armstrong et al., 1999). In mammals, type 3 deiodinase, encoded by Dio3, is expressed in the placenta and fetal tissues, including the brain (Kaplan and Yaskoski, 1981; Escámez et al., 1999; Kester et al., 2004). This expression pattern has suggested a protective role for Dio3 in immature neural tissues, recently supported by the finding of deafness in $\mathrm{Dio3}^{-/-}$mice $(\mathrm{Ng}$ et al., 2009b). However, little else is known of Dio3 functions in the nervous system.

Cones are the receptor cells for daylight and color vision, but the controls that direct cone development are incompletely defined. Most mammals possess dichromatic color vision, conferred by differential expression of $\mathrm{M}$ and $\mathrm{S}$ opsin photopigments for sensitivity to medium-long and short wavelengths of light, respectively (Lyubarsky et al., 1999; Mollon, 1999; Nathans, 1999). Cones are generated before birth and express $S$ then $M$ opsins as they migrate to their mature location in the retina (Carter-Dawson and LaVail, 1979b; Szél et al., 1993; Xiao and Hendrickson, 2000). Mice deficient for thyroid hormone receptor $\beta 2$ (TR $\beta 2$ ) lack $\mathrm{M}$ opsin but retain S opsin, revealing a critical role for thyroid hormone in opsin patterning ( $\mathrm{Ng}$ et al., 2001). To identify additional controls over cone development, we investi- 
gated deiodinases as potential modifiers of TR $\beta 2$ activity. We found that type 3 deiodinase is expressed in the immature retina and that $\mathrm{Dio}^{-/-}$mice lose cones by neonatal cell death. Cone survival was rescued by deletion of TR $\beta 2$, demonstrating that $\operatorname{TR} \beta 2$ is an arbiter of both cone death and opsin patterning. The results suggest that type 3 deiodinase keeps hormonal exposure of immature cones below a deleterious threshold, thereby allowing both survival and opsin patterning.

\section{Materials and Methods}

Mouse strains. Mice carrying the Dio3 mutation (Hernandez et al., 2006) were backcrossed for two generations onto a C57BL/6J background. $D_{i o} 3^{+/-}$parents were crossed to generate $+/+$and $-/-$progeny for analyses. Whenever possible, analyses were performed on $+/+$ and $-/-$ littermates. To avoid possible maternal hormonal influences, progeny for analysis were not obtained from $-/-$ dams. Both male and female $-1-$ progeny were analyzed, and both displayed similar retinal phenotypes. $D i o 3^{-/}$pups had reduced survival and represented $<5 \%$ of progeny of crosses of Dio3 $^{+/-}$parents. Thrb2 ${ }^{-/-}$mice (Ng et al., 2001) possessed a mixed $129 / \mathrm{Sv} \times \mathrm{C} 57 \mathrm{BL} / 6 \mathrm{~J} \times \mathrm{DBA}$ background. Survival rates of $D i o 3^{-/-}$pups improved after crossing onto the background of the Thrb2 ${ }^{-1-}$ strain. The cone phenotype was similar on both backgrounds. For T3 treatments, C57BL/6J $+/+$ pups were given a daily injection (subcutaneous) of saline vehicle or T3 in saline (0.1 or $1.5 \mu \mathrm{g}$ of T3 in 10 $\mu$ l volume) at postnatal day 0 ( $\mathrm{P} 0)$ to $\mathrm{P} 3$. To measure the level of serum T3 attained $2 \mathrm{~h}$ after injection, serum was pooled from four to six pups at $\mathrm{P} 4,1 \mathrm{~d}$ older than groups taken for retinal analysis, to increase the small volumes of serum obtainable. Pregnant C57BL/6J female mice were made hypothyroid by treatment with methimazole $(0.05 \% \mathrm{w} / \mathrm{v})$ and potassium perchlorate $(1.0 \% \mathrm{w} / \mathrm{v})$ in the drinking water beginning at gestational day 14 and continuing until progeny were analyzed (shown in supplemental Fig. S1, available at www.jneurosci.org as supplemental material). Mouse experiments were performed in accordance with $\mathrm{Na}-$ tional Institutes of Health guidelines and institutional protocols at $\mathrm{Na}$ tional Institute of Diabetes and Digestive and Kidney Diseases/National Institutes of Health and University of Pennsylvania.

Deiodinase and hormone measurements. Type 3 deiodinase activity was measured as described previously (Hernandez et al., 2006) for individual pairs of eyes for groups of 10-30 embryos from two to five litters. Activity was determined by measuring, after separation by paper chromatography, the amount of $\left[{ }^{125} \mathrm{I}\right] 3,3^{\prime}$-di-iodothyronine (T2) produced after incubation of tissue homogenate for $1 \mathrm{~h}$ with $2 \mathrm{~nm}\left[{ }^{125} \mathrm{I}\right] \mathrm{T} 3$ in the presence of $50 \mathrm{~mm}$ dithiothreitol. To avoid variation from potential further deiodination of $\mathrm{T} 2$ product into mono-iodothyronine (T1), assay conditions were used that maintained a deiodination rate below 30\% to ensure linearity with respect to the amount of protein included. Under these conditions, no significant T1 was generated and type 3 deiodinase activities were calculated as T2 generated per hour and milligram of protein. Radiolabeled substrate was obtained from PerkinElmer Life and Analytical Sciences. Serum total T4 and T3 levels were determined by radioimmunoassay with Coat-A-Count reagents (Diagnostic Systems Laboratories) (Hernandez et al., 2006).

Immunohistochemistry and in situ hybridization. Cryosections $(10 \mu \mathrm{m}$ thick) were blocked with PBS containing $1.5 \%$ goat serum, $0.1 \%$ BSA, and $0.4 \%$ Triton X-100 and incubated with primary antibodies overnight at room temperature and then with biotinylated goat anti-rabbit antibodies. Detection was performed with a Vector ABC Elite kit with 3,3'diaminobenzidine (Vector Laboratories). Antibody sources and dilutions for use included the following: rabbit anti-opsin blue (AB5407; 1:1000; Millipore Bioscience Research Reagents), rabbit anti-opsin red/ green (AB5405; 1:1000; Millipore Bioscience Research Reagents), mouse monoclonal anti-rhodopsin (04886; 1:2000; Sigma-Aldrich), rabbit antiactivated caspase 3 (1:500; Promega), and rabbit anti-TR $\beta 2(1: 1000)(\mathrm{Ng}$ et al., 2009a). Secondary antibodies were FITC-conjugated goat antirabbit (Vector Laboratories) and AlexaFluor 568 goat anti-rabbit (Invitrogen). Terminal deoxynucleotidyl transferase-mediated biotinylated UTP nick end labeling (TUNEL) analysis was performed with the In Situ Cell Death Detection kit (Roche). Digoxigenin-labeled riboprobes were generated from a Dio3 cDNA amplified by PCR from mouse brain RNA and cloned into pGEM11 (Promega) corresponding to rat Dio3 bases 78-525 (GenBank accession number RNU24282). Riboprobes were applied to $10 \mu \mathrm{m}$ cryosections with colorimetric detection as described previously (Lu et al., 2009).

Histology and transmission electron microscopy. Retinae were fixed overnight in PBS containing 2\% paraformaldehyde and 3\% glutaraldehyde at $4^{\circ} \mathrm{C}$, dehydrated through $30,50,70$, and $100 \%$ ethanol, and then embedded in glycol methacrylate (Polysciences). Histological 3- $\mu \mathrm{m}$ thick microtome sections were stained with hematoxylin and eosin. Cone and rod nuclei were counted in 165 - $\mu \mathrm{m}$-long fields of outer nuclear layer $(\mathrm{ONL})$ in two representative fields per section on three sections per eye for three mice per genotype. Statistical tests were based on the Student's $t$ test. For transmission electron microscopy, retinae (three mice per group) were postfixed in $1 \%$ osmium tetroxide in PBS for $1 \mathrm{~h}$ and embedded in Spurr's plastic resin. Sections $(600-800 \AA)$ were analyzed on a Carl Zeiss transmission electron microscope (JFE Enterprises).

Electroretinogram recordings. Electroretinogram (ERG) recording methods were described previously (Lyubarsky et al., 1999, 2002). In brief, adult mice were dark-adapted overnight then anesthetized with a mixture containing (in $\mathrm{mg} / \mathrm{g}$ body weight) 25 ketamine, 10 xylazine, and 1000 urethane and placed on a stage maintained at $38^{\circ} \mathrm{C}$. The pupil was dilated with 1\% tropicamide saline solution (Mydriacil; Alconox). A recording electrode was placed in electrical contact with the cornea. A stainless steel bite bar served as both reference and ground electrode. ERGs were recorded with a differential amplifier with bandwidth $0.1 \mathrm{~Hz}$ to $1 \mathrm{kHz}$ and sampled at $240 \mu$ s intervals (Axotape 2 software and acquisition board; Molecular Devices). Signals were processed offline with custom software developed with MATLAB (MathWorks). Recordings were made in an $8 \times 8 \times 14$ inch aluminum Faraday cage coated internally with UV-reflecting white paint (Eastman Kodak), which served also as a ganzfeld. For a few experiments, an Espion Electrophysiology System (Diagnosys LLC) was used. Rod responses were suppressed with constant green light at 10 photopic $\mathrm{cd} / \mathrm{m}^{2}$. To measure $\mathrm{S}$ opsin responses, a UV light-emitting diode (LED) was used with a peak at $367 \mathrm{~nm}$, halfbandwidth of $15 \mathrm{~nm}$, and intensities of 0.0001. 0.0005, 0.0015, 0.005, and 0.05 photopic $\mathrm{cd} / \mathrm{m}^{2}$. To measure $\mathrm{M}$ opsin responses, an LED was used with a peak at $520 \mathrm{~nm}$, half-bandwidth of $35 \mathrm{~nm}$, and intensities of 0.5 , $1.5,5.0,15.0$, and $25.0(\mathrm{P}) \mathrm{cd} / \mathrm{m}^{2}$. Sampling frequency was $100 \mathrm{~Hz}$ with 20 responses averaged per recorded trace.

Light stimulation. Methods for light stimulation and calibration of light stimuli were described previously (Lyubarsky et al., 1999). For monochromatic stimuli, flash intensities are reported in photons $\mu \mathrm{m}^{-2}$ at the retina and represent the number of quanta incident on a unit of area of the retina. The utility of using this parameter, which cannot be measured directly, is that it allows for uniform representation of stimulus intensities for both pigmented and albino mice. To obtain intensities at the retina, light sources were calibrated in units of photons $\mu \mathrm{m}^{-2}$ at the cornea with a calibrated photodiode positioned at the location of the mouse eye in the ganzfeld stimulator as described previously (Lyubarsky and Pugh, 1996; Lyubarsky et al., 1999). The stimulus intensity at the retina was computed as follows: (intensity at the retina) $=$ (intensity at the cornea $) \times($ pupil area $) /($ retinal area $)$. For pigmented mice, values for pupil and retina areas were taken as 3.1 and $14.1 \mathrm{~mm}^{2}$, respectively (Lyubarsky and Pugh, 1996). We found that, for a given illuminance, rhodopsin bleach rate in situ is threefold higher for albino mice than for pigmented mice (Lyubarsky et al., 2004); therefore, we assumed that an effective pupil area for albino mice is $3 \times 3.14=9.4 \mathrm{~mm}^{2}$. Intensity of broadband orange $(\lambda>530 \mathrm{~nm})$ stimuli targeting $\mathrm{M}$ opsin is reported in equivalent $500 \mathrm{~nm}$ photons $\mu \mathrm{m}^{-2}$; intensity of achromatic white flashes is reported in equivalent photons $\mu \mathrm{m}^{-2}$ at absorbance maximums of respective visual pigments (Lyubarsky et al., 1999).

Measurements of the spectral sensitivity of the cone-driven b-wave. Methods for measuring spectral sensitivity of the cone-driven b-wave have been described previously (Lyubarsky et al., 1999, 2002). Conedriven responses were isolated by suppressing rod activity with steady achromatic background light delivering $\sim 10,000$ photoisomerizations $\operatorname{rod}^{-1} s^{-1}$. The measure of sensitivity reported here, the "fractional sen- 
sitivity," represents the fraction of the saturating cone b-wave suppressed per photon $\mu \mathrm{m}^{-2}$ in the linear range of the cone b-wave response.

Single-cone recordings. Responses of cones to brief flashes of calibrated monochromatic light were recorded with suction pipettes as described previously (Nikonov et al., 2006). In brief, the perinuclear region of two to five cells in the ONL of retinal slices was drawn into a suction pipette, and photocurrent (i.e., the suppression of the circulating current) was measured in response to light. The contribution of rods was suppressed by a steady $500 \mathrm{~nm}$ background of 10,000 photons $\mu \mathrm{m}^{-2} \mathrm{~s}^{-1}$ that suppressed the circulating current of the rods.

\section{Results}

\section{Requirement for type 3 deiodinase in cone development}

To investigate a role for deiodinases in photoreceptor development and function, deiodinase activity was analyzed in mouse eye homogenates. Type 3 deiodinase activity was relatively abundant in homogenates from embryonic day 13 (E13) until birth. Activity declined postnatally but persisted at low levels into adulthood (Fig. $1 \mathrm{~A}$ ). Northern blot analysis showed that expression of Dio3 mRNA paralleled that of type 3 deiodinase activity (Fig. $1 B$ ). The major $2.2 \mathrm{~kb}$ Dio3 mRNA in eye was similar to that in the cochlea but was smaller than the most abundant $2.8 \mathrm{~kb}$ mRNA in adult brain; both mRNAs are thought to encode active enzyme (Dentice et al., 2007; $\mathrm{Ng}$ et al., 2009b). Little type 2 (Dio2) or type 1 (Dio1) deiodinase mRNA or activity was detected in eye, although weak Dio2 mRNA expression was detected at later postnatal stages (data not shown). In situ hybridization localized Dio3 mRNA in all neural retina layers (outer neuroblast, inner neuroblast, and ganglion cell layers) in the embryo and in the neonate (Fig. 1C). This widespread expression pattern is likely to include undifferentiated neuroblasts as well as many differentiating but immature cell types. The broad expression pattern persisted at postnatal stages (shown at P2) but with a general decline in signal intensity, consistent with the decreased enzyme activity levels. Although individual cell types could not be identified with currently available reagents, the broad expression pattern suggested a role for type 3 deiodinase in restricting the availability of thyroid hormone for target cells in the immature retina.

A requirement for type 3 deiodinase in cone development was revealed in Dio3 ${ }^{-/-}$mice (Hernandez et al., 2006), which lacked type 3 deiodinase activity in eye (Fig. $1 D$ ). To avoid possible variation in maternal influence over the phenotype, all progeny studied were derived from $+/-$ parents. Normally, $M$ and $S$ opsins are expressed in opposing distribution gradients across the retina, with $\mathrm{M}$ opsin predominating in superior and $\mathrm{S}$ opsin in inferior zones, whereas cones in middle regions express varying proportions of both opsins (Szél et al., 1993; Applebury et al., 2000). Adult $\mathrm{Dio}^{-/-}$mice lacked $\sim 80 \%$ of both $\mathrm{M}$ opsinpositive $(+)$ and $\mathrm{S}$ opsin ${ }^{+}$cones (Fig. $2 A$; counts in Fig. $6 B$ ). Among the remaining cones in $\mathrm{Dio3}^{-/-}$mice, there was an unusual incidence of cones with opsins located aberrantly throughout the cell body, axon, and pedicle rather than in the outer segment. The results suggested that Dio3 was primarily required for the survival and maturation of cones rather than for opsin patterning.

Histological analysis showed that adult $\mathrm{Dio3}^{-/-}$mice at 3 months of age had $\leq 20 \%$ of normal total cone numbers but normal rod numbers (Fig. $2 B, D$ ). Rods, the second major class of photoreceptor, mediate vision in dim light and express rhodopsin photopigment. Rods can be distinguished from cones by their greater abundance and their more compact, chromatin-dense nuclei compared with the larger, less dense nuclei of cones (Carter-Dawson and LaVail, 1979a). The cone loss in Dio3 ${ }^{-1-}$
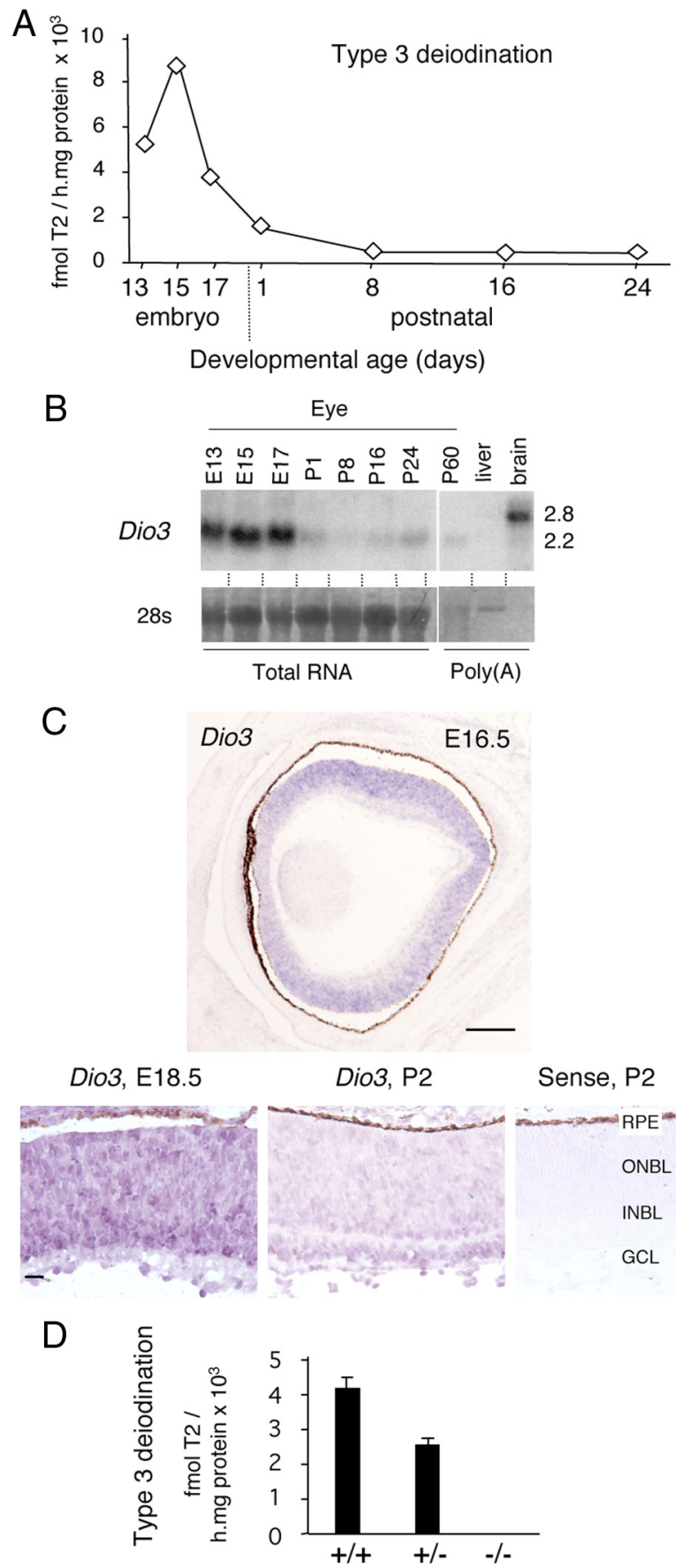

Figure 1. Type 3 deiodinase expression in retinal development. $\boldsymbol{A}$, Type 3 deiodinase activity in mouse eye homogenates. Activity was determined for pools of eyes at the ages indicated. Note that the $x$-axis scale differs at embryonic and postnatal ages. $\boldsymbol{B}$, Northern blot detection of Dio3 mRNA in eye development. The main $2.2 \mathrm{~kb}$ Dio3 mRNA in eye was similar to that reported in the cochlea (Ng et al., 2009b). Brain and liver are positive and negative control tissues for Dio3 expression. 28S, rRNA control for RNA integrity detected by methylene blue staining. C, In situ hybridization detected Dio3 mRNA in all layers of the immature neural retina at E16.5 (top). Higher-magnification (bottom) shows signals for Dio3 at E18.5 and P2 and a control sense strand probe at P2. GCL, Ganglion cell layer; RPE, retinal pigmented epithelium. Scale bars: top, $50 \mu \mathrm{m}$; bottom, $20 \mu \mathrm{m}$. D, Loss of retinal type 3 deiodination in Dio $3^{-1-}$ mice. Plots show mean $\pm S D$ activity determined for individual pairs of eyes from $7+/+, 21+/-$, and $12-/$ - embryos at E18.5.

mice was confirmed by transmission electron microscopy, which also showed that some residual cones had a less distinct morphology than usual (Fig. 2C). Dio $3^{-1-}$ mice showed no overt morphological abnormality in the retina other than loss of cones. 


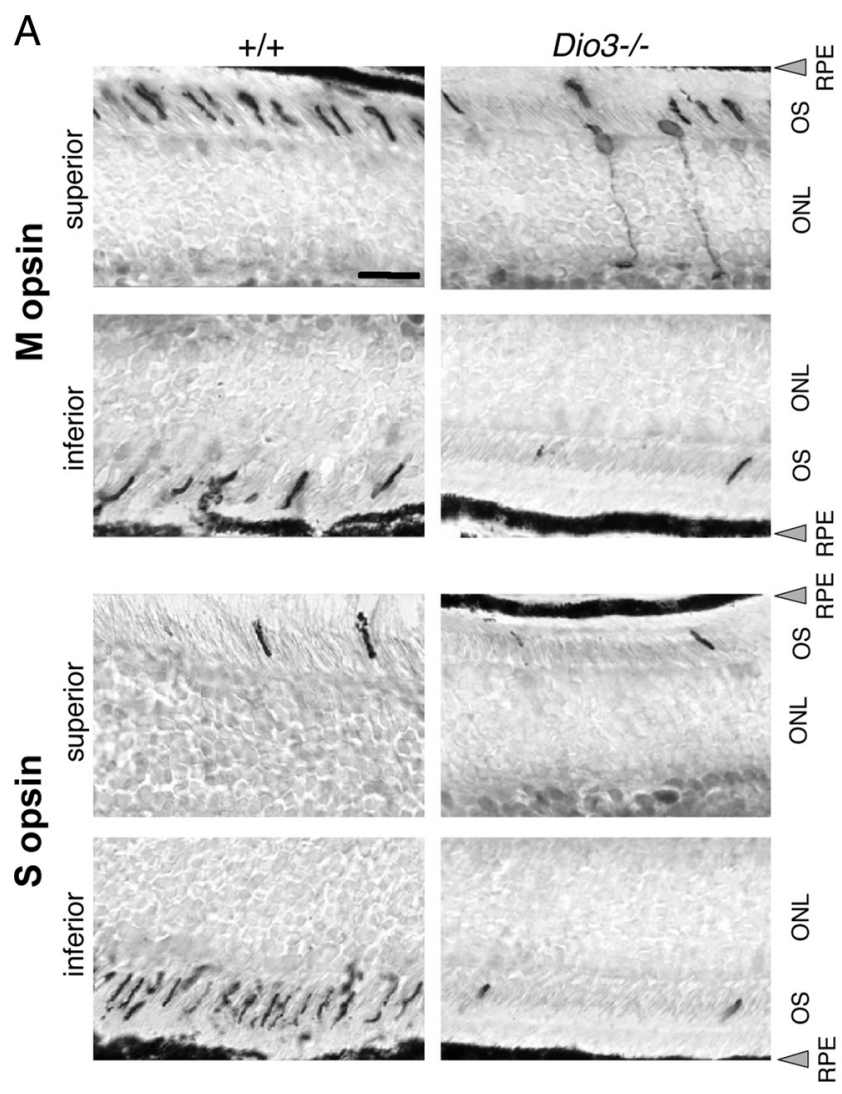

B
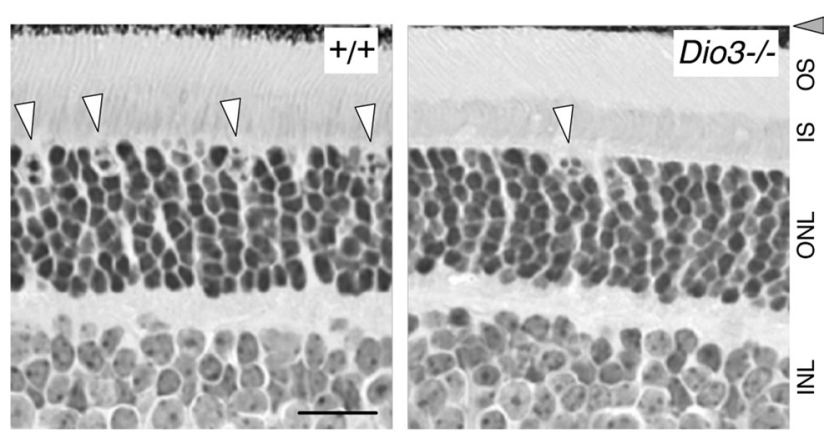

C
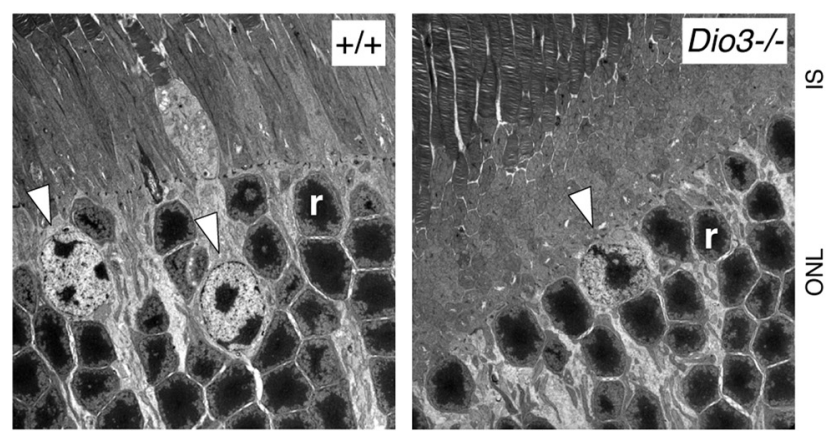

$\mathrm{D}$

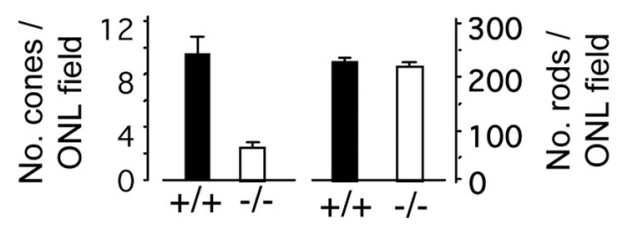

Figure 2. Requirement for Dio3 in cone development. $A$, Immunostaining of retinal sections for $M$ and S opsin ${ }^{+}$cones in 2-month-old $+/+$and Dio ${ }^{-/-}$mice. In $+/+$mice, $M$ and S opsins are detected in outer segments (OS) with opposing distribution gradients across the superior-inferior axis of the retina. Dio $3^{-1-}$ mice lacked most M and S opsin ${ }^{+}$cones; some residual cones displayed opsin mislocalized in the cell body, axon, and pedicle. Sections were lightly counterstained with hematoxylin. INL, Inner nuclear layer; RPE, retinal pigmented epithelium (gray arrowhead). Scale bar, $20 \mu \mathrm{m}$. B, Retinal histology. Methacrylate sections stained with hematoxylin and eosin showing absence of most cones in adult Dio $3^{-1}$ mice. Arrowheads identify cone nuclei at the outer edge of the photoreceptor layer (ONL). Cones are sparse in the ONL, most of which consists of small, dense rod nuclei. IS, Inner segment layer. Scale bar, $20 \mu \mathrm{m}$. C, Transmission electron micrographs of retina showing cones (arrowheads) and rods $(r)$ in 3-month-old mice ( $2500 \times$ magnification). Fewer cone nuclei were present in Dio $3^{-1-}$ mice than in $+/+$ mice, and some remaining cones showed a less distinct morphology than in $+1+$ mice. $\boldsymbol{D}$, Counts of cone and rod nuclei. Counts were determined as described in Materials and Methods and are shown as means \pm SD determined for $165-\mu \mathrm{m}$-long ONL fields on $3-\mu \mathrm{m}$-thick methacrylate sections. Dio $3^{-/-}$mice had $\sim 20 \%$ of $+/+$ cone numbers $(p<0.0001)$. Rod numbers were not significantly different.

\section{Loss of immature cones by cell death in $\mathrm{Dio3}^{-/-}$mice}

Analysis of early cone markers showed that cones were generated in Dio ${ }^{-/-}$embryos but were lost somewhat abruptly after P1 (Fig. 3A). A population of newly generated $\mathrm{TR} \beta 2^{+}$cones was present in the outer neuroblastic layer (ONBL) of both $D i o 3^{-1-}$ and wild type $(+/+)$ embryos at E16.5. Also, S opsin ${ }^{+}$cones were detected in both Dio3 $^{-/-}$and $+/+$pups at P1, but, by P5, few S opsin $^{+}$cells remained in Dio3 ${ }^{-/-}$mice. Rhodopsin expression was not overtly altered in Dio3 ${ }^{-1-}$ mice.

Analysis of cell death markers showed that Dio $^{-1-}$ pups lost cones by cell death (Fig. $3 B$ ). In $+/+$ pups at P2, TUNEL $^{+}$cells were detected in the ganglion cell layer and inner neuroblastic layer (INBL) and at lower incidence in the ONBL, in accord with the normal pattern of developmental cell death in the mouse retina (Young, 1984). In $+/+$ pups, most S opsin ${ }^{+}$cells were located in the ONBL, and few $(1.5 \%)$ were colabeled by TUNEL. In contrast, in Dio $3^{-1-}$ pups at $\mathrm{P} 2,64 \%$ of remaining S opsin ${ }^{+}$ cells were $\mathrm{TUNEL}^{+}$, suggesting that cones accounted for most of the increase in dying cells (Fig. $3 C$ ). Total S opsin ${ }^{+}$cone numbers were $\sim 50 \%$ reduced below normal in $D i o 3^{-1-}$ pups by $\mathrm{P} 2$.

The cell death incidence in $\mathrm{Dio}^{-1-}$ mice was elevated only transiently in the early postnatal period. Compared with $+/+$ mice at P2, Dio $3^{-1-}$ pups had an eightfold increase in activated caspase $3^{+}$cells in the ONBL and a threefold increase in the INBL
(Fig. $3 D, E$ ). By P8, Dio3 ${ }^{-/-}$mice had a declining incidence of dying cells with only a small (approximately twofold) increase in activated caspase $3^{+}$cells in the ONL compared with $+/+$mice. At $\mathrm{P} 24$, almost no dying cells were identified in any retinal layer in Dio $^{-1-}$ or $+/+$ mice. Thus, Dio3 ${ }^{-/-}$mice displayed a coneselective, transient increase in developmental cell death rather than a widespread or progressive degeneration of the retina.

Immature cones in Dio3 ${ }^{-/-}$mice were also abnormally located in the retina. Normally, neonatal cones align near the outer edge of the ONBL and over the next few days migrate inwardly toward the INBL before migrating back to the outer edge of the ONL after P12 (Rich et al., 1997). In Dio3 ${ }^{-1-}$ mice at P1, S opsin ${ }^{+}$ cells were correctly aligned in the ONBL but, by $\mathrm{P} 2, \mathrm{~S}$ opsin ${ }^{+}$cells were more widely dispersed in the ONBL and INBL (Fig. 3B). Cell death in $\mathrm{Dio3}^{-/-}$mice was not a consequence of such mislocation because $\mathrm{S}$ opsin ${ }^{+} / \mathrm{TUNEL}^{+}$double-labeled cells were detected in both the ONBL and INBL.

\section{T3-induced death of immature cones}

The ability of type 3 deiodinase to inactivate thyroid hormone suggested that cone loss in $\mathrm{Dio}^{-/-}$mice resulted from unconstrained stimulation by T3. To test the hypothesis that $\mathrm{T} 3$ was the mediator of cone loss, $+/+\mathrm{C} 57 \mathrm{BL} / 6 \mathrm{~J}$ pups were injected daily with increasing T3 doses or saline vehicle between P0 and P3, a 


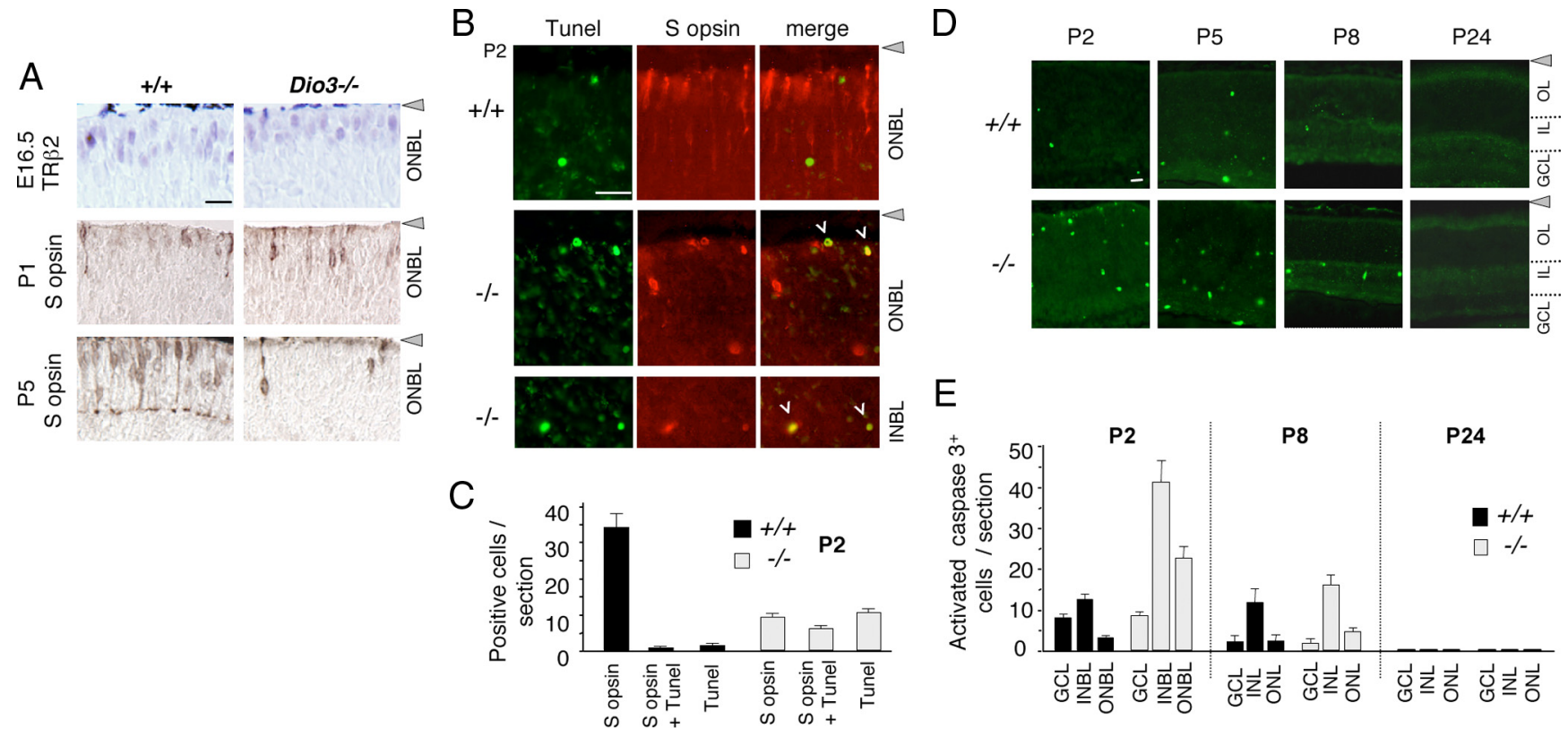

Figure 3. Cone cell death in Dio $3^{-/-}$pups. $A$, Immunostaining for early cone markers. A newly generated cone population $\left(\operatorname{TR} \beta 2^{+}\right)$was detected in both $+/+$and Dio $3^{-/-}$mice at E16.5.

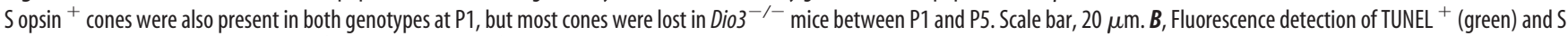
opsin $^{+}$(red) cells in $+/+$and Dio $3^{-/-}$pups at P2. Dio3 ${ }^{-/-}$pups exhibit increased numbers of TUNEL ${ }^{+}$and TUNEL ${ }^{+} / S$ opsin ${ }^{+}$double-positive cells (yellow, merge). In $+/+$pups, most $S$ opsin $^{+}$cones resided near the edge of the ONBL, but, in Dio ${ }^{-1-}$ pups, many of the remaining $S$ opsin ${ }^{+}$cones were dispersed in the INBL and ONBL. Scale bar, $20 \mu \mathrm{m} . \mathrm{C}$ Counts of $S$ opsin ${ }^{+}$, TUNEL $^{+}$, and double-positive (TUNEL ${ }^{+} / S$ opsin ${ }^{+}$) cells at P2. Counts were determined in midretinal fields (400- $\mu \mathrm{m}$-long fields) on $10 \mu \mathrm{m}$ cryosections. Groups, $n=6$ eyes from 3 mice. D, Immunostaining for activated caspase $3^{+}$cells in retina in $+/+$and Dio $3^{-/-}$mice during development at postnatal stages. Positive cell numbers increased in Dio $3^{-/-}$mice in the 0NBL and INBL at P2-P8. IL, Inner layers (inner neuroblastic at P2, P5 or inner nuclear at P8, P24); 0 L, outer layers (outer neuroblastic at P2, P5 or outer nuclear at P8, 24); GCL, ganglion cell layer. Scale bar, $20 \mu \mathrm{m} . \boldsymbol{E}$, Counts of activated caspase $3^{+}$cells determined over the full length of midretinal, $10-\mu \mathrm{m}$-thick cryosections. Groups, $n=4-8$ eyes from $2-4$ mice per age.

A P24
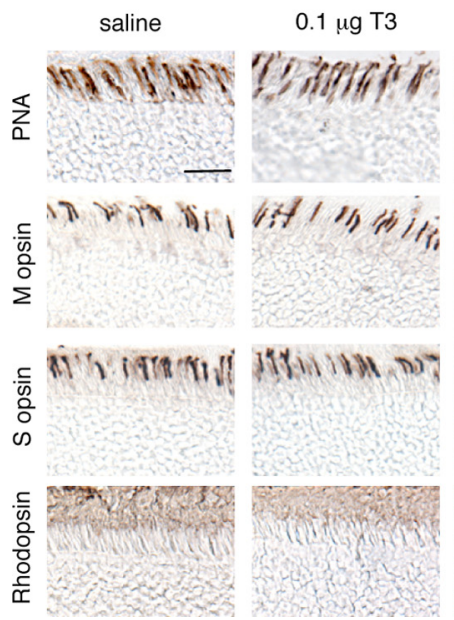

B

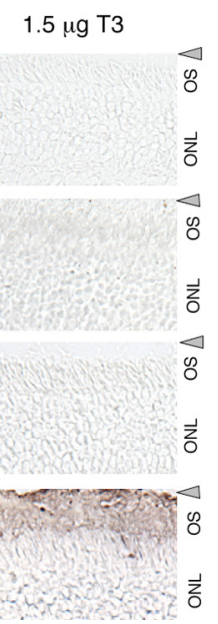

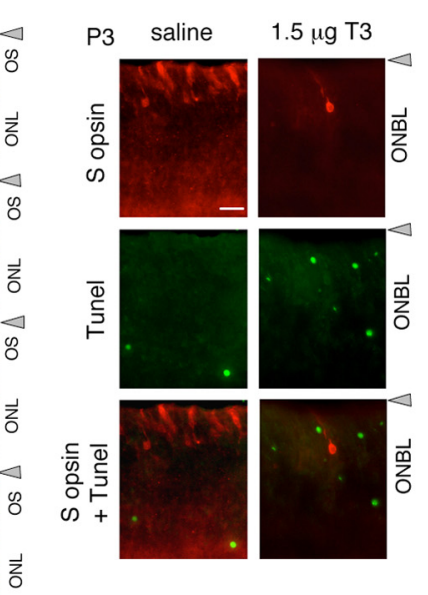

$\mathrm{C}_{\text {P24 }}$

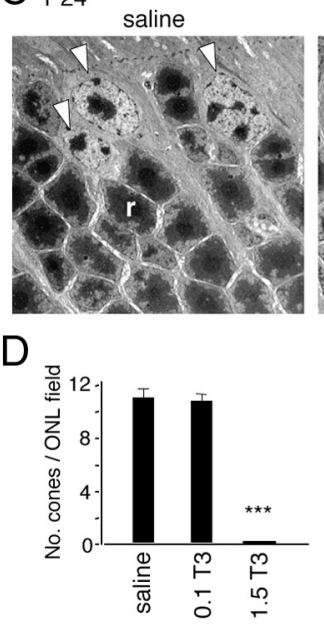

$1.5 \mu \mathrm{g}$ T3
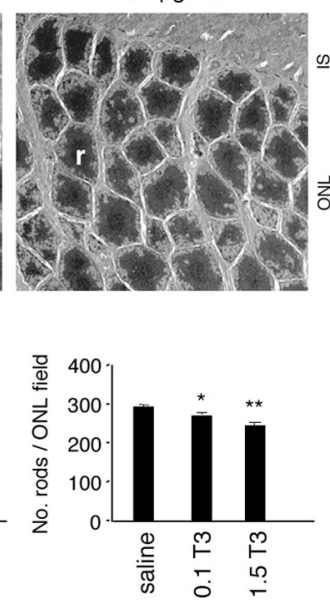

Figure 4. Excessive T3 leads to cone loss in neonatal $+/+$ mice. $A$, Analysis of cone and rod markers at P24 after previous injections (daily subcutaneously) of saline or high ( $0.1 \mu \mathrm{g}$ ) or extremely high $(1.5 \mu \mathrm{g})$ T3 doses in +/+ pups from PO-P3. The highest T3 doses eliminated identifiable cones using any marker (S opsins, M opsins, PNA). Rhodopsin ${ }^{+}$rods remained intact. OS, Outer segment. Scale bar, $20 \mu \mathrm{m}$. B, Analysis of S opsin and TUNEL staining in retina in pups at P3 after injections of $1.5 \mu \mathrm{g}$ of T3 given daily from P0-P3. T3 gave a near complete loss of $S$ opsin ${ }^{+}$cones and increased numbers of TUNEL ${ }^{+}$cells. A rare residual S opsin ${ }^{+}$cell is shown. Scale bar, $20 \mu \mathrm{m}$. C, Transmission electron micrographs of $+/+$ mouse retina at P24 after previous injections with saline or $1.5 \mu \mathrm{g}$ of T3 at P0-P3 (2500 $\times$ magnification). Rods (r) and cones (arrowheads) are indicated. T3 treatment eliminated cones. IS, Inner segment. D, Cone and rod counts in $+/+$ mice determined at P24 after previous injection at P0-P3 of saline, or 0.1 or $1.5 \mu \mathrm{g} / \mathrm{d}$ T3. A dose of $1.5 \mu \mathrm{g} / \mathrm{d} \mathrm{T3}$ eliminated cones $\left({ }^{* * *} p=3.8 \times 10^{-10}\right)$, but $0.1 \mu \mathrm{g} / \mathrm{d} \mathrm{T3}$ gave no significant cone loss ( $p=0.78)$ compared with saline treatment. Rod numbers were slightly decreased by $0.1 \mu \mathrm{g} / \mathrm{d} \mathrm{T} 3\left({ }^{*} p=0.02\right)$ and $1.5 \mu \mathrm{g} / \mathrm{d} \mathrm{T} 3\left({ }^{* *} p=7.1 \times 10^{-5}\right.$ ). Rod and cone nuclei were counted in $210-\mu \mathrm{m}$-long $0 \mathrm{NL}$ fields on 3- $\mu \mathrm{m}$-thick methacrylate sections. Groups, $n=5$ eyes from 5 mice.

period that encompassed the peak phase of cone death in Dio $^{-/-}$mice (Fig. $4 A$ ). It was predicted that the highest T3 doses would overcome the protective role of type 3 deiodinase to cause cone loss. Indeed, saline or moderately high T3 doses $(0.1 \mu \mathrm{g} / \mathrm{d}$, s.c.) produced no overt changes in $\mathrm{M}$ or $\mathrm{S}$ opsin ${ }^{+}$cells when analyzed at P24. However, extremely high T3 doses $(1.5 \mu \mathrm{g} / \mathrm{d})$ eliminated cones, demonstrated by loss of $\mathrm{M}$ and $\mathrm{S}$ opsins, loss of reactivity to peanut agglutinin (PNA), a general marker of cones, and absence of morphologically identifiable cone nuclei (Fig. $4 A, C)$. These $\mathrm{T} 3$ doses marginally reduced rod numbers (Fig. $4 D)$. These very high T3 doses $(1.5 \mu \mathrm{g} / \mathrm{d})$ gave increased numbers of TUNEL ${ }^{+}$cells and a near complete loss of S opsin ${ }^{+}$cells at P3 
A
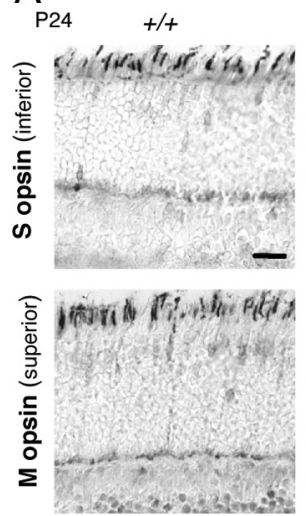
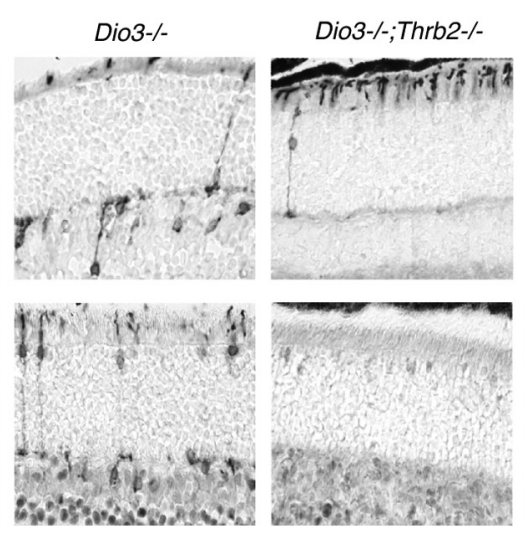

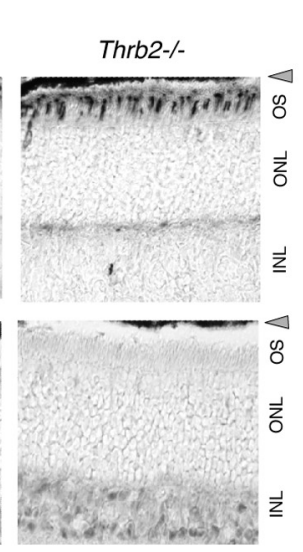

B
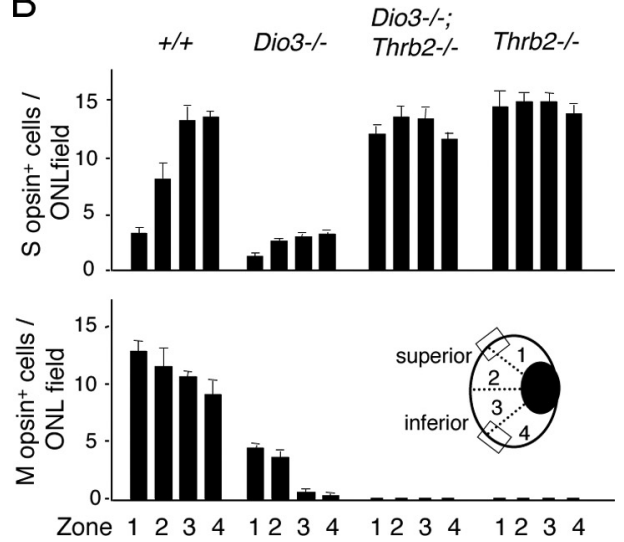

Figure 5. TR $\beta 2$ mediates cone loss in Dio $3^{-/-}$mice. $A$, Immunostaining for $M$ and S opsins in retina of mice of genotypes indicated at P24. Dio $3^{-/-}$mice exhibited reduced cone numbers and also an incidence of mislocated opsin ${ }^{+}$cells in the INL and unusual cells with staining in the axon and pedicle. Sopsin ${ }^{+}$cones were recovered in Dio $^{-/-}$; Thrb2 ${ }^{-/-}$mice compared with Dio $3^{-/-}$ mice. In Dio3 ${ }^{-1-} ; T_{h r b 2} 2^{-1-}$ mice, recovered cones were almost exclusively S opsin ${ }^{+}$and lacked M opsin, as in Thrb2 ${ }^{-/-}$mice. Most recovered cones were correctly located at the edge of the $0 \mathrm{NL}$

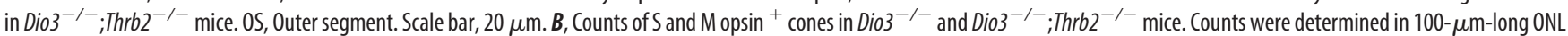
fields on $10 \mu \mathrm{m}$ cryosections in each of the four zones shown in the inset eye diagram. Boxes indicate zones in superior and inferior retina. Groups, $n=6$ eyes from 3 mice.

(Fig. $4 B$ ), consistent with cone loss resulting from a similar process as in $\mathrm{Dio3}^{-1-}$ pups. As described previously ( $\mathrm{Ng}$ et al., $2009 \mathrm{~b}$ ), injections of 0.1 and $1.5 \mu \mathrm{g}$ T3 (subcutaneously) in neonates resulted in $\sim 70$-fold and $\sim 270$-fold increases, respectively, in serum T3 levels above levels in saline-treated or untreated $+/+$ pups at $\mathrm{P} 4$ when measured $\sim 2 \mathrm{~h}$ after injection.

To establish further that T3 was the agent of cone cell death, Dio3 $^{-1-}$ mice were made hypothyroid during development. $\mathrm{Dio3}^{+/-}$parents were crossed, and pregnant females were treated with the antithyroid agent methimazole from gestational day 14.5, as described previously (Lu et al., 2009). Dio3 ${ }^{-/-}$pups in these litters had threefold to fivefold increased S opsin ${ }^{+}$cell numbers at P6 compared with untreated Dio3 ${ }^{-/-}$pups, although numbers were still below normal (supplemental Fig. S1, available at www. jneurosci.org as supplemental material). The partial recovery may be explained by the technical difficulty of inducing complete hypothyroidism within embryonic and neonatal tissues.

\section{Cone loss in $\mathrm{Dio3}^{-/-}$mice requires TR $\beta 2$}

To establish that cone loss in $\mathrm{Dio}^{-/-}$mice was a direct response of cones to T3, the cone-specific thyroid hormone receptor TR $\beta 2$ was deleted from $\mathrm{Dio3}^{-/-}$mice. It was predicted that loss of TR $\beta 2$ would make cones resistant to T3 action. Mice with the combined genotype Dio3 ${ }^{-/-}$; Thrb2 $2^{-/-}$showed a marked rescue of cone numbers (Fig. 5). Almost all of these recovered cones were correctly located near the outer edge of the ONL, and all cones were $\mathrm{S}$ opsin ${ }^{+}$. Little or no M opsin was detectable, in accord with the known requirement for $\mathrm{TR} \beta 2$ for $\mathrm{M}$ opsin induction ( $\mathrm{Ng}$ et al., 2001). The results support the conclusion that, in $\mathrm{Dio3}^{-/-}$mice, cone cell death and cone mislocation are cone-intrinsic functions mediated by excessive T3 stimulation of TR $\beta 2$.

\section{Cone and rod function in $\mathrm{Dio}^{-/-}$mice}

Analysis of ERG responses showed that, in accord with the loss of most cones, Dio3 ${ }^{-1-}$ mice exhibited a fivefold reduced magnitude of the cone b-wave generated in response to intense, saturating achromatic flashes that excite both $\mathrm{M}$ and $\mathrm{S}$ opsins as compared with $+/+$ mice (Fig. $6 \mathrm{~A}$, black traces). In Dio ${ }^{-1-}$ mice, although the absolute magnitude of the cone b-wave was much reduced, intense orange flashes $(>530 \mathrm{~nm})$ that photoisomerize only M opsin (Lyubarsky et al., 1999) elicited near sat- urating responses, indicating the presence of some amount of $\mathrm{M}$ opsin in the remaining cones (Fig. $6 \mathrm{~A}$, green traces).

In Dio3 $^{-/-} ;$Thrb2 $2^{-/-}$mice, the rescue of cones correlated with a recovery of saturating cone b-waves with magnitudes comparable with those in $+/+$ mice (Fig. 6B). However, in $\mathrm{Dio3}^{-/-}$; Thrb2 $2^{-/-}$mice, in accord with the lack of $\mathrm{M}$ opsin, a saturating orange flash elicited only a small response of $\sim 20 \%$ of the maximal amplitude of the cone b-wave observed in $+/+$ mice. Cone responses in $\mathrm{Dio3}^{-/-}$; Thrb2 $2^{-/-}$mice thus resembled those of Thrb2 $2^{-1-}$ mice in which response to short wavelengths was retained but response to medium-long wavelengths was reduced (Ng et al., 2001).

Given that cones in $\mathrm{Dio3}^{-/-} ;$Thrb2 $2^{-/-}$mice expressed almost exclusively $S$ opsin, we measured the sensitivity of the cone b-wave response for flashes of $360 \mathrm{~nm}$, a wavelength near the maximum of the spectral sensitivity of S opsin. Families of responses not exceeding $30 \%$ of the saturating response (i.e., within the linear range of the intensity-response relation for the cone b-wave) were elicited by a series of $360 \mathrm{~nm}$ flashes of increasing intensity. Sensitivity to $360 \mathrm{~nm}$ light was enhanced approximately fivefold in $\mathrm{Dio3}^{-/-}$; Thrb2 $2^{-/-}$mice compared with $+/+$ mice (Fig. $6 B, D$ ). Thrb2 $2^{-1-}$ mice showed a similar, although smaller (2.1-fold), enhanced sensitivity for $360 \mathrm{~nm}$ light (Fig. 6D). Previously, Thrb2 $2^{-/-}$mice were reported to exhibit near normal, not enhanced, responses to short wavelengths based on a stimulus of $450 \mathrm{~nm}$ (Ng et al., 2001), a difference from the present results that is explained by the $450 \mathrm{~nm}$ stimulus used previously being suboptimal for measuring $\mathrm{S}$ opsin sensitivity in mice.

Rod function was assessed for dark-adapted mice with responses to dim flashes that elicited saturating rod b-wave responses and bright flashes that elicited mixed rod and cone responses. The bright flash saturates the a-wave response of normal rods and cones, but, because of the 30-fold greater abundance of rods, the composite a-wave arises almost completely from the suppression of the transduction current of rods (Lyubarsky et al., 1999). The amplitude of both b- and a-waves measured in this way showed a slight but significant reduction in Dio ${ }^{-/-}$mice compared with $+/+$mice (Fig. $6 C$, top and bottom, respectively). In $\mathrm{Dio}^{-1-} ; \mathrm{Thrb}^{-1-}$ mice, the rod b-wave amplitude was normal, whereas the a-wave was apparently reduced, although this was not statistically significant. These results 

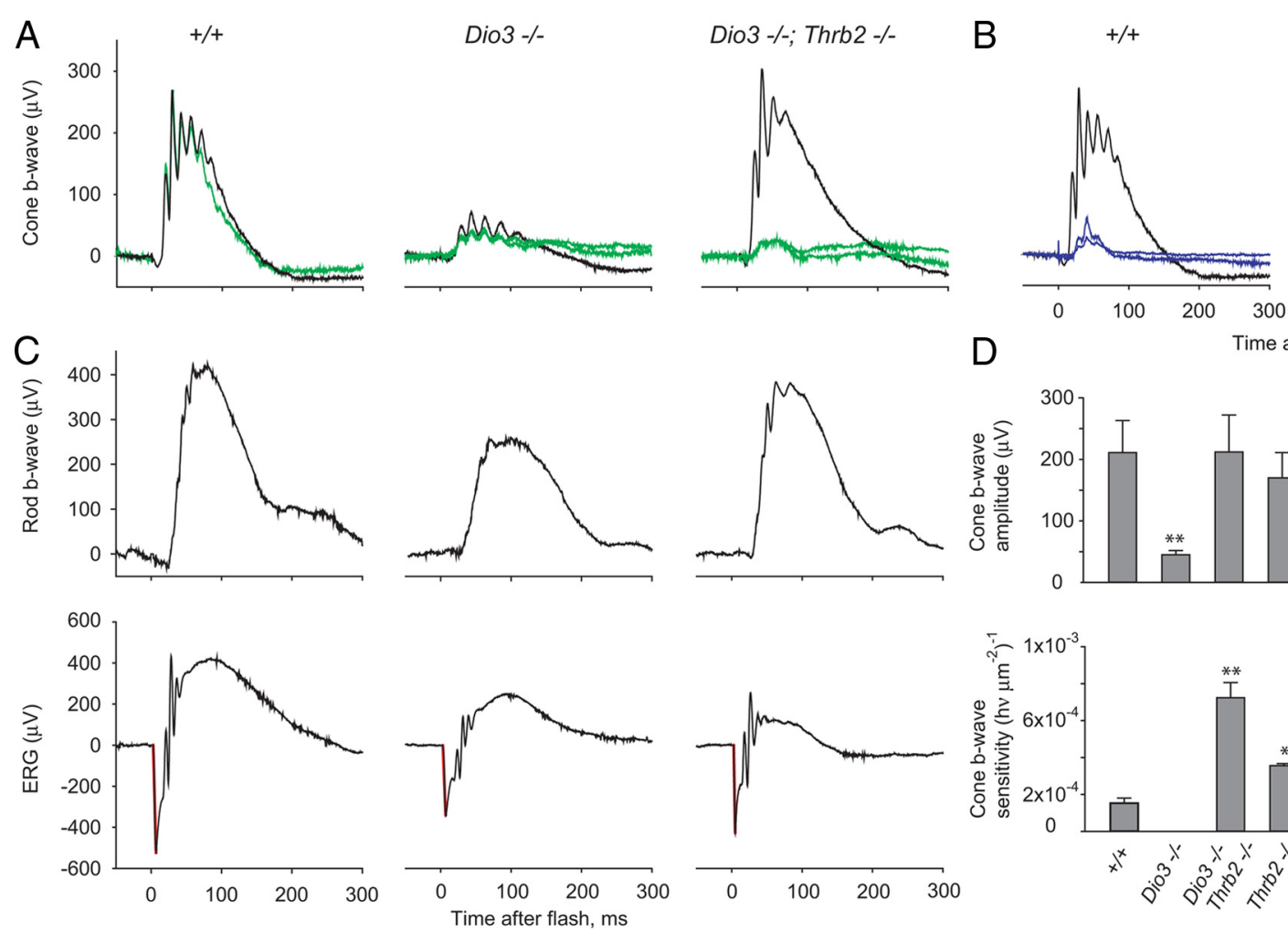

Dio3 -/-; Thrb2 -/-

D
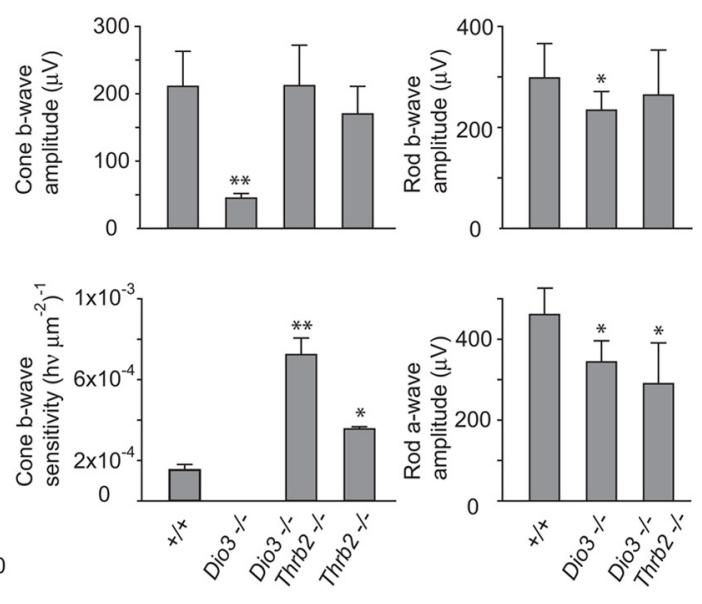

Figure 6. Electroretinogram responses in Dio3 $3^{-1-}$ and Dio3 $3^{-1-} ;$ Thrb2 ${ }^{-1-}$ mice. A, Full-field cone-driven responses to achromatic and long wavelength stimuli. Black traces, Saturating responses to bright ( 2000 scotopic $\mathrm{cd} \mathrm{m}^{-2}$ ) white flashes (total cone response); green traces, responses to orange $(\lambda>530 \mathrm{~nm})$ flashes (M opsin ${ }^{+}$cone response). In $+/+$ mice, an orange flash of 600 scotopic $\mathrm{cd} \mathrm{m}^{-2}$ elicits a response almost identical to the saturating response to a white stimulus, indicating that most cones express some $M$ opsin (Lyubarsky et al., 1999). In Dio3 ${ }^{-/-}$mice, amplitudes of saturating responses to white and orange flashes are approximately fivefold smaller than in $+/+$mice. In Dio $3^{-/-} ;$Thrb $^{-/-}$ mice, white flashes elicit saturating cone responses of normal magnitude, but orange flashes of any intensity ( 70 and $600 \mathrm{scotopic} \mathrm{cd} \mathrm{m}^{-2}$ ) ( green traces) generate only a small response consistent with lack of M opsin. B, Cone-driven ERGs generated by short wavelength stimuli. Black traces, Saturating responses elicited with bright (2000 scotopic cd $\mathrm{m}^{-2}$ ) white flashes. Blue traces, Responses to ultraviolet $\left(360 \mathrm{~nm}\right.$ ) flashes with estimated intensities of (photons $\mu \mathrm{m}^{-2}$ at the retina) 660 and $1320 \mathrm{for}+/+$ mice and 140 and 250 for Dio $3^{-/-} ; T_{h r b 2}^{-/-}$ mice. Similar magnitudes of response are elicited with approximately fivefold dimmer stimulus in Dio3 $3^{-1-} ;$ Thrb $2^{-/-}$than in $+/+$mice. $C$, ERGs of dark-adapted mice. Top, Responses to $\operatorname{dim}\left(0.02\right.$ scotopic cd s $\left.\mathrm{m}^{-2}\right)$ flashes of green $(510 \mathrm{~nm})$ light. In these conditions, ERGs are represented by rod-driven (scotopic) b-waves of saturating magnitude and reflect primarily the magnitude of the circulating current of the rod bipolar cells. Bottom, Responses to bright ( 200 scotopic $\mathrm{cd} \mathrm{s} \mathrm{m}^{-2}$ ) achromatic flashes that saturate the a-wave amplitude, which is proportional to the circulating current of the rod photoreceptors. The corneal negative a-wave component is highlighted in red. $D$, Bar charts of mean \pm SD values for ERG components and properties illustrated in $\boldsymbol{A}-\boldsymbol{C}$ for groups of mice: $10+1+, 7$ Dio $3^{-1-}, 6$ Dio $3^{-1-} ;$ Thrb $2^{-1-}, 8$ Thrb $^{-/-}$. Statistically significant differences in mutant mouse groups compared with $+/+$ mice are indicated: ${ }^{*} p<0.05 ;{ }^{* *} p<0.01$ (one-tailed $t$ tests).

indicate that rods are only mildly affected in $\mathrm{Dio3}^{-/-}$and $\mathrm{Dio}^{-/-}$; Thrb2 $2^{-/-}$mice.

\section{Properties of single cones in $\mathrm{Dio3}^{-/-} ; \mathrm{Thrb}^{-/-}$ and Thrb2 $^{-1-}$ mice}

In the ERG, the cone b-wave represents the response of cone bipolar cells, and thus its enhancement in $\mathrm{Dio3}^{-1-} ; \mathrm{Thrb}^{-1-}$ mice could reflect either a gain in function of $S$ opsin phototransduction in cones or enhanced transmission and responsiveness of bipolar cells driven by $\mathrm{S}$ cones. To distinguish between these possibilities, we studied single-cone responses in $\mathrm{Dio3}^{-/-}$; Thrb2 $2^{-1-}$ and Thrb2 $2^{-1-}$ mice (Fig. 7). In mice of these genotypes, cones had normal kinetic properties, as revealed by comparison with $+/+$ cones in terms of their response families (Fig. $7 A, D, G)$, amplification $(B, E, H)$, flash sensitivity, and time to recover $(C, F, I)$. Because all these properties were extracted from responses to $360 \mathrm{~nm}$ flashes, it can be concluded that the increased b-wave sensitivity to $360 \mathrm{~nm}$ light (Fig. 7D) does not arise from altered $\mathrm{S}$ opsin-driven phototransduction of individual cones but rather in alterations in synaptic transmission to bipolar cells or in properties of the bipolar cells.

Single-cone recordings confirmed that the large loss of cone b-wave sensitivity to green light in $\mathrm{Dio3}^{-/-} ; \mathrm{Thrb}^{-/-}$or
Thrb2 $2^{-1-}$ mice (Fig. 7A) arises from diminished coexpression of $\mathrm{M}$ opsin in $\mathrm{S}$ opsin dominant cones (Fig. $7 \mathrm{~J}$ ). Individual ventral cones of $+/+$ mice all exhibit a primary mode of sensitivity at 360 $\mathrm{nm}$, the $\lambda_{\max }$ of mouse $S$ opsin, and a secondary mode at $510 \mathrm{~nm}$, the $\lambda_{\max }$ of mouse $\mathrm{M}$ opsin (Fig. $7 \mathrm{~J}$, white circles). In ventral cones of $+/+$ mice, this secondary mode is on average $\sim 30$-fold less sensitive than the primary mode but nonetheless reflects detectable coexpression of $\mathrm{M}$ opsin in $\mathrm{S}$ opsin dominant cones (Nikonov et al., 2006). In contrast, ventral cones of $T h r b 2^{-/-}$and $\mathrm{Dio3}^{-1-}$; Thrb2 ${ }^{-1-}$ mice exhibited a nearly 100 -fold additional reduction in sensitivity below the average $+/+$ level to green light (Fig. 7J, blue circles and symbols, respectively). Although the sample of individual cones from the mutant mice is small, the loss of midwave sensitivity is extremely reliable: the probability that the sensitivities at $500 \mathrm{~nm}$ of the Thrb2 $2^{-/-}$or Dio3 ${ }^{-1-}$;Thrb2 $2^{-1-}$ cones could be those of a random sample of the population of ventral $+/+$ cones is negligible.

\section{Discussion}

\section{Dual functions of thyroid hormone in cone development}

This study reveals that cone survival is sensitive to T3 and that excessive T3 exposure in neonatal mice eliminates cones. Cone loss results from administration of $\mathrm{T} 3$ excesses or by inactivation 

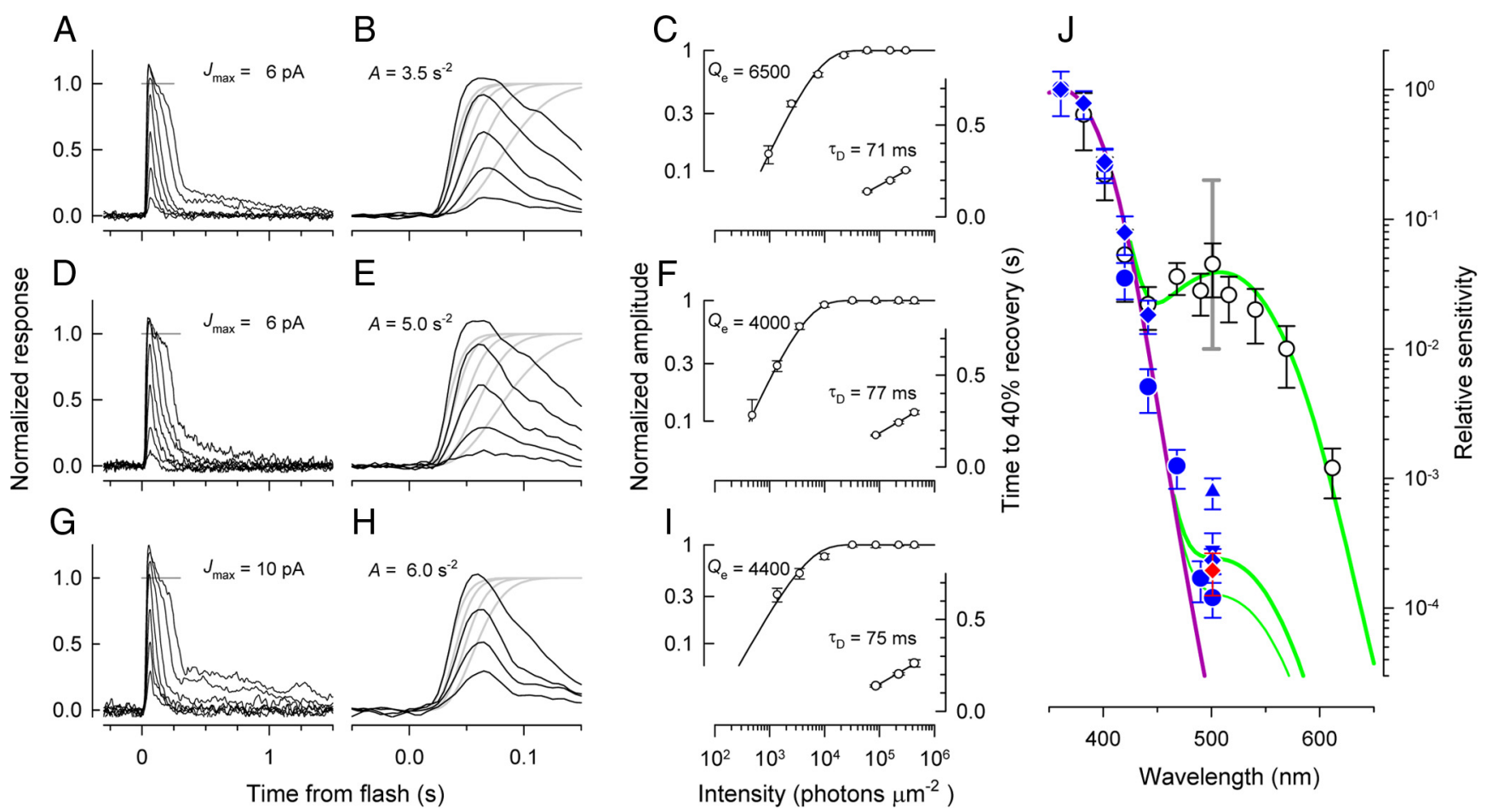

Figure 7. Properties of $S$ opsin dominant cones in ventral retina of $+/+, D i 03^{-1-} ;$ Thrb $2^{-/-}$, and $T h r b 2^{-/-}$mice. Each row presents data recorded from a single cone of a $+/+(A-C)$, a Thrb2 $2^{-/-}(\boldsymbol{D}-\boldsymbol{F})$, and a Dio3 ${ }^{-1-} ; T_{h r b 2^{-/-}}(\boldsymbol{G}-\boldsymbol{I})$ mouse. $\boldsymbol{A}, \boldsymbol{D}, \mathbf{G}$, Response families, normalized by the estimated maximum response amplitude corresponding to the complete suppression of the light sensitive current (short gray horizontal lines). $\boldsymbol{B}, \boldsymbol{E}, \boldsymbol{H}$, Responses from corresponding panels in the first column on the expanded timescale (black traces) together with theoretical predictions of the response rising phases (gray traces) (Pugh and Lamb, 1993; Nikonov et al., 2006); the estimated values of the amplification constant $A$ for each cone are shown. $C, F, I$, Normalized amplitude versus flash intensity data (left ordinates) and time to $40 \%$ recovery versus flash intensity data (right ordinates) for the corresponding response families in the first column. The amplitude versus flash intensity data were fitted with exponential saturation functions: the intensities $Q_{e}$ that drive the cell to $1 / e$ of saturation are shown. Recovery times for responses to saturating flashes were fitted with straight lines to estimate dominant recovery time constants $\left(\tau_{\mathrm{D}}\right)$ (Pepperberg et al., 1992). J, Plot of the spectral sensitivity of one $+/+$ cone (open circles), four Thrb2 ${ }^{-/-}$cones (blue circles, diamonds, triangles, and inverted triangles, each representing a single cone), and one Dio $3^{-/-} ; T_{h r b 2}{ }^{-1-}$ cone (red diamond; for a second Dio3 ${ }^{-/} ; T_{\text {hrb2 }}{ }^{-1-}$ cone, responses at $501 \mathrm{~nm}$ were too insensitive to be measured). The data of each genotype are describable as the combination of opsin template spectra (Lamb, 1995) for opsins with $\lambda_{\max }$ at $360 \mathrm{~nm}$ (mouse $S$ opsin) and $508 \mathrm{~nm}$ (mouse M opsin), respectively: the S opsin template is scaled to unity, whereas the M opsin template has been scaled to fit the data above $500 \mathrm{~nm}$. The scaling factor provides an estimate of the fraction of M opsin coexpression in S dominant cones (Nikonov et al., 2006, 2008). Gray error bar at $508 \mathrm{~nm}$ plots a $99 \%$ confidence interval for M opsin coexpression in S dominant cones of $+/+$ mice derived from 30 cones.

of type 3 deiodinase, an enzyme that degrades thyroid hormone. Susceptibility to T3-mediated cell death presents a paradox for the cone because some amount of T3 is necessary for correct dorsoventral patterning of $\mathrm{M}$ and $\mathrm{S}$ opsins. Hypothyroid mice have retarded expression of $\mathrm{M}$ opsin and an extended distribution of $S$ opsin in cones across the retina, a phenotype resembling that of Thrb2 ${ }^{-/-}$mice (Lu et al., 2009). Our findings suggest that type 3 deiodinase solves this paradox for the cone by lowering exposure to T3 to a level that prevents death but promotes survival and opsin patterning (Fig. 8). The widespread expression of Dio 3 in the retina may be advantageous in providing a sink for T3 from any source before it reaches the target cone cell.

The surviving cones in $\mathrm{Dio}^{-/-}$mice may represent a small population that escape death because of variability in hormonal exposure at the individual cell level. This possibility is supported by the finding that extremely high T3 doses $(>250$-fold above normal) given to $+/+$ pups eliminate all cones, presumably by exposing cones to far greater T3 levels than occur in Dio $3^{-1-}$ pups. Dio $3^{-1-}$ mice have abnormalities in the pituitary-thyroid axis that cause a premature twofold to threefold rise in serum $\mathrm{T} 3$ levels at early postnatal stages (Hernandez et al., 2006; Ng et al., 2009 b). However, in $+1+$ pups, T3 at levels $\sim 70$-fold above normal did not kill cones, indicating that absence of protection by type 3 deiodinase, rather than the moderately increased T3 level, is the primary cause of cone death in $\mathrm{Dio}^{-{ }^{-1}}$ mice.

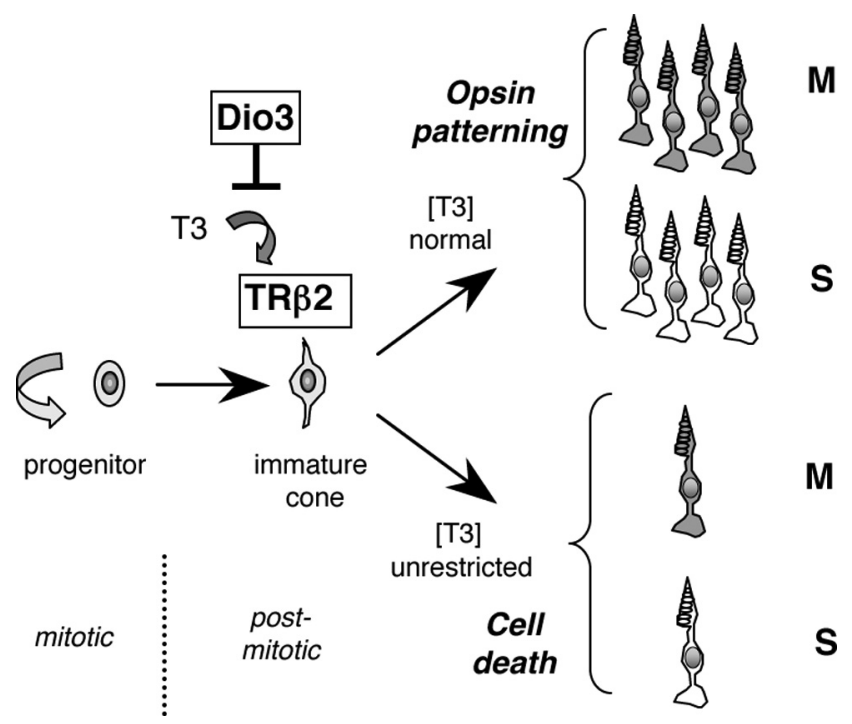

Figure 8. Diagram of the central role of TR $\beta 2$ in cone maturation and the role of Dio3 in limiting stimulation by $T 3$ to beneficial levels. TR $\beta 2$ is expressed in newly generated cones in mice and directs $M$ opsin induction and differential patterning of $M$ and $S$ opsins in cones over the retina. Some amount of T3 is necessary for TR $\beta 2$ to induce $M$ opsin and promote $M$ and $S$ opsin patterning. However, type 3 deiodinase constrains the exposure to T3 to prevent TR $\beta 2$ mediated cone cell death. 
Cones progress through distinct phases of sensitivity to T3 and are susceptible to T3-induced death only during the first postnatal week. By the second postnatal week, cones become resistant to death but sensitive to induction of M opsin (Roberts et al., 2006; Lu et al., 2009). These phases may be defined by the net action of several progressively changing factors, including serum thyroid hormone levels and levels of receptor and deiodinase expression. A previous study reported that T3 excesses at P0-P3 suppressed $\mathrm{S}$ opsin expression but left $\mathrm{PNA}^{+}$cones intact when examined at P3 (Roberts et al., 2006). It is likely that such high T3 doses ultimately would have killed most cones had analysis been performed at the later ages studied in the present work. Our results do not exclude the suggested negative regulation of $S$ opsin expression by T3 in neonates ( $\mathrm{Ng}$ et al., 2001; Shibusawa et al., 2003; Roberts et al., 2006) but reveal cone death to be the overriding outcome when $\mathrm{T} 3$ exceeds a threshold at early stages.

\section{Genetic cooperation and specificity of T3 action}

This study reveals how close functional cooperation between receptor and deiodinase genes directs the maturation of a specific cell type, the cone, in response to T3. The findings also demonstrate the need to constrain thyroid hormone receptor activity at certain developmental stages, complementing previous evidence for mechanisms that enhance responses to T3 in target tissues. Known means of enhancing T3 action include amplification of T3 levels by type 2 deiodinase in the auditory system and brain in mice (Ng et al., 2004; Galton et al., 2007) and the specific uptake of thyroid hormone in brain by membrane transporters, as revealed by $М С T 8$ transporter mutations in human X-linked mental retardation (Visser et al., 2008). Within the cell, the transcriptional coactivator TFIIH, which is mutated in human trichothiodystrophy, has been reported to stabilize thyroid hormone receptor binding to brain target genes in a mouse model (Compe et al., 2007). Mechanisms that both constrain and augment T3 action may prove to be equally important for any given response in neurodevelopment.

The results indicate how $\mathrm{T} 3$ coordinates development of cone photoreceptors within the changing developmental context of the organism as a whole. A progressive rise in thyroid hormone levels in the bloodstream is a prerequisite for maturation of many tissues, but tissues vary in the threshold of T3 required and when T3 is required. Early retinal Dio3 expression protects neonatal cones from a deleterious response to T3, whereas the postnatal decline of Dio3 expression may contribute to the later induction of $\mathrm{M}$ opsin ( $\mathrm{Lu}$ et al., 2009). Type 3 deiodination has been described in postnatal rat retinal extracts with a similar decline as occurs in the mouse (Ientile et al., 1984). Type 3 deiodinase activity or mRNA is also detected in frog, trout, and chick eye (Marsh-Armstrong et al., 1999; Plate et al., 2002; Trimarchi et al., 2008). Dio3 controls additional functions in non-mammalian species, such as eye growth in Xenopus laevis (Marsh-Armstrong et al., 1999). However, a role for Dio3 in cone survival may be conserved because, in immature trout, thyroxine treatment induces a partial, apoptotic loss of UV-sensitive cones, a process that occurs naturally during migration to a marine environment (Allison et al., 2006).

\section{Cone function in the absence of TR $\beta 2$ and type 3 deiodinase}

In the absence of TR $\beta 2$ or of both TR $\beta 2$ and type 3 deiodinase, mice produce normal numbers of functional cones that express $\mathrm{S}$ opsin but little or no $\mathrm{M}$ opsin. In both Thrb2 $2^{-/-}$and $\mathrm{Dio3}^{-/-}$; Thrb2 $2^{-1-}$ mice, individual cones have essentially normal physiological properties with normal activation and inactivation kinetics. One may therefore speculate that the response of cones to T3, mediated by Thrb and Dio3 genes, represents an adaptation acquired by an existing cone developmental program with the benefit of enhancing visual capability. Thus, mice lacking TR $\beta 2$ possess a basic visual system based on rods for dim light vision and $\mathrm{S}$ cones for daylight vision. TR $\beta 2$ promotes $\mathrm{M}$ opsin expression, thereby enhancing daylight vision in the visible region of the spectrum and color discrimination. However, TR $\beta 2$ also confers the disadvantage of susceptibility to T3-mediated cone death such that the accompanying protection given by type 3 deiodinase is essential for enhancing visual capability.

We did observe that, in Dio3 ${ }^{-/-}$; Thrb2 $2^{-1-}$ or Thrb2 $2^{-/-}$mice, the cone ERG was significantly more sensitive to short wave light than in $+/+$ mice. $S$ opsin expression is only marginally increased in adult Thrb2 $2^{-/-}$mice (Ng et al., 2001) and is unlikely to explain fully the enhanced response. It is more likely that enhanced sensitivity occurs at the level of the synapse with the bipolar neurons that generate the cone b-wave response and may involve indirect changes in the postsynaptic bipolar neuron pool or presynaptic changes in the cone. In mice lacking Nrl transcription factor, the retina has no rods but instead overproduces excess cones (Mears et al., 2001; Daniele et al., 2005). Because these cones drive a b-wave with essentially normal amplitude, it follows that the cones can make functional synapses with rod bipolar cells (Strettoi et al., 2004). Thus, TR $\beta 2$ may regulate genes that control not only opsin patterning and cone death but also the properties of first-order synapses in the retina. Future study may reveal distinct sets of target genes for each of these functions of TR $\beta 2$.

We also detected a mild sensitivity of rods to T3 because Dio $3^{-/-}$mice had slightly reduced rod function. Also, extremely high $\mathrm{T} 3$ doses in $+/+$ mice marginally reduced rod numbers. Although TR $\beta 2$ is cone specific, T3 excesses may also act on other more widely expressed thyroid hormone receptor isoforms that may exist at low levels in rods. Alternatively, cone loss may indirectly influence rods through loss of cone-released factors or loss of cone-promoted cell contacts. The latter possibilities are in accord with reports of impaired rod function in human achromatopsia, in which cones are thought to carry the primary defect (Khan et al., 2007; Moskowitz et al., 2009).

\section{Implications for retinal disease}

Human DIO3 mutations are unknown but, based on the Dio ${ }^{-/-}$ mouse phenotype, could result in achromatopsia or rod monochromacy in which cone but not rod function is lost (Michaelides et al., 2004). Any such disorder may be syndromic because Dio3 $^{-1-}$ mice also exhibit small stature and hearing loss (Hernandez et al., 2006; Ng et al., 2009b). Human rod monochromacy with small stature has been associated with maternal uniparental disomy of chromosome 14, which carries the DIO3 gene (Wiszniewski et al., 2007). Although the patient also carried a mutation in CNGB3, which is involved in other cases of achromatopsia, a contribution by DIO3 is not excluded. In mice, Dio3 is imprinted and is preferentially expressed from the paternal allele (Hernandez et al., 2002). Thus, maternal uniparental disomy may reduce DIO3 expression to cause overexposure to T3, thereby exacerbating the cone impairment. It is also possible that human congenital hyperthyroidism (Fisher, 2003) predisposes to cone impairment, although defects may be mild given the protective role of type 3 deiodinase. TR $\beta 2$ is detected in human fetal cones and in retinoblastoma cells that possess cone properties (Xu et al., 2009). Thus, enhancing T3 exposure may potentially provide a means of killing retinoblastoma tumor cells. 


\section{References}

Allison WT, Dann SG, Veldhoen KM, Hawryshyn CW (2006) Degeneration and regeneration of ultraviolet cone photoreceptors during development in rainbow trout. J Comp Neurol 499:702-715.

Applebury ML, Antoch MP, Baxter LC, Chun LL, Falk JD, Farhangfar F, Kage K, Krzystolik MG, Lyass LA, Robbins JT (2000) The murine cone photoreceptor: a single cone type expresses both $\mathrm{S}$ and $\mathrm{M}$ opsins with retinal spatial patterning. Neuron 27:513-523.

Becker KB, Stephens KC, Davey JC, Schneider MJ, Galton VA (1997) The type 2 and type 3 iodothyronine deiodinases play important roles in coordinating development in Rana catesbeiana tadpoles. Endocrinology 138:2989-2997.

Bianco AC, Salvatore D, Gereben B, Berry MJ, Larsen PR (2002) Biochemistry, cellular and molecular biology, and physiological roles of the iodothyronine selenodeiodinases. Endocr Rev 23:38-89.

Cao XY, Jiang XM, Dou ZH, Rakeman MA, Zhang ML, O'Donnell K, Ma T, Amette K, DeLong N, DeLong GR (1994) Timing of vulnerability of the brain to iodine deficiency in endemic cretinism. N Engl J Med 331: 1739-1744.

Carter-Dawson LD, LaVail MM (1979a) Rods and cones in the mouse retina. I. Structural analysis using light and electron microscopy. J Comp Neurol 188:245-262.

Carter-Dawson LD, LaVail MM (1979b) Rods and cones in the mouse retina. II. Autoradiographic analysis of cell generation using tritiated thymidine. J Comp Neurol 188:263-272.

Compe E, Malerba M, Soler L, Marescaux J, Borrelli E, Egly JM (2007) Neurological defects in trichothiodystrophy reveal a coactivator function of TFIIH. Nat Neurosci 10:1414-1422.

Daniele LL, Lillo C, Lyubarsky AL, Nikonov SS, Philp N, Mears AJ, Swaroop A, Williams DS, Pugh EN Jr (2005) Cone-like morphological, molecular, and electrophysiological features of the photoreceptors of the $\mathrm{Nrl}$ knockout mouse. Invest Ophthalmol Vis Sci 46:2156-2167.

Dentice M, Luongo C, Huang S, Ambrosio R, Elefante A, Mirebeau-Prunier D, Zavacki AM, Fenzi G, Grachtchouk M, Hutchin M, Dlugosz AA, Bianco AC, Missero C, Larsen PR, Salvatore D (2007) Sonic hedgehoginduced type 3 deiodinase blocks thyroid hormone action enhancing proliferation of normal and malignant keratinocytes. Proc Natl Acad Sci U S A 104:14466-14471.

Escámez MJ, Guadaño-Ferraz A, Cuadrado A, Bernal J (1999) Type 3 iodothyronine deiodinase is selectively expressed in areas related to sexual differentiation in the newborn rat brain. Endocrinology 140:5443-5446.

Fisher DA (2003) Neonatal hyperthyroid screening. J Pediatr 143:285-287.

Galton VA, Wood ET, St Germain EA, Withrow CA, Aldrich G, St Germain GM, Clark AS, St Germain DL (2007) Thyroid hormone homeostasis and action in the type 2 deiodinase-deficient rodent brain during development. Endocrinology 148:3080-3088.

Hernandez A, Fiering S, Martinez E, Galton VA, St Germain D (2002) The gene locus encoding iodothyronine deiodinase type 3 (Dio3) is imprinted in the fetus and expresses antisense transcripts. Endocrinology 143:4483-4486.

Hernandez A, Martinez ME, Fiering S, Galton VA, St Germain D (2006) Type 3 deiodinase is critical for the maturation and function of the thyroid axis. J Clin Invest 116:476-484.

Ientile R, Macaione S, Russo P, Pugliese G, Di Giorgio RM (1984) Phenolic and tyrosyl ring deiodination in thyroxine from rat retina during postnatal development. Eur J Biochem 142:15-19.

Kaplan MM, Yaskoski KA (1981) Maturational patterns of iodothyronine phenolic and tyrosyl ring deiodinase activities in rat cerebrum, cerebellum, and hypothalamus. J Clin Invest 67:1208-1214.

Kester MH, Martinez de Mena R, Obregon MJ, Marinkovic D, Howatson A, Visser TJ, Hume R, Morreale de Escobar G (2004) Iodothyronine levels in the human developing brain: major regulatory roles of iodothyronine deiodinases in different areas. J Clin Endocrinol Metab 89:3117-3128.

Khan NW, Wissinger B, Kohl S, Sieving PA (2007) CNGB3 achromatopsia with progressive loss of residual cone function and impaired rodmediated function. Invest Ophthalmol Vis Sci 48:3864-3871.

Lamb TD (1995) Photoreceptor spectral sensitivities: common shape in the long-wavelength region. Vision Res 35:3083-3091.

Lu A, Ng L, Ma M, Kefas B, Davies TF, Hernandez A, Chan CC, Forrest D (2009) Retarded developmental expression and patterning of retinal cone opsins in hypothyroid mice. Endocrinology 150:1536-1544.

Lyubarsky AL, Pugh EN Jr (1996) Recovery phase of the murine rod photo- response reconstructed from electroretinographic recordings. J Neurosci 16:563-571.

Lyubarsky AL, Falsini B, Pennesi ME, Valentini P, Pugh EN Jr (1999) UVand midwave-sensitive cone-driven retinal responses of the mouse: a possible phenotype for coexpression of cone photopigments. J Neurosci 19:442-455.

Lyubarsky AL, Lem J, Chen J, Falsini B, Iannaccone A, Pugh EN Jr (2002) Functionally rodless mice: transgenic models for the investigation of cone function in retinal disease and therapy. Vision Res 42:401-415.

Lyubarsky AL, Daniele LL, Pugh EN Jr (2004) From candelas to photoisomerizations in the mouse eye by rhodopsin bleaching in situ and the light-rearing dependence of the major components of the mouse ERG. Vision Res 44:3235-3251.

Marsh-Armstrong N, Huang H, Remo BF, Liu TT, Brown DD (1999) Asymmetric growth and development of the Xenopus laevis retina during metamorphosis is controlled by type III deiodinase. Neuron 24:871-878.

Mears AJ, Kondo M, Swain PK, Takada Y, Bush RA, Saunders TL, Sieving PA, Swaroop A (2001) Nrl is required for rod photoreceptor development. Nat Genet 29:447-452.

Michaelides M, Hunt DM, Moore AT (2004) The cone dysfunction syndromes. Br J Ophthalmol 88:291-297.

Mollon JD (1999) Color vision: opsins and options. Proc Natl Acad Sci U S A 96:4743-4745.

Morreale de Escobar G, Obregón MJ, del Rey FE (2004) Maternal thyroid hormones early in pregnancy and fetal brain development. Best Pract Res Clin Endocrinol Metab 18:225-248.

Moskowitz A, Hansen RM, Akula JD, Eklund SE, Fulton AB (2009) Rod and rod-driven function in achromatopsia and blue cone monochromatism. Invest Ophthalmol Vis Sci 50:950-958.

Nathans J (1999) The evolution and physiology of human color vision: insights from molecular genetic studies of visual pigments. Neuron 24:299-312.

Ng L, Hurley JB, Dierks B, Srinivas M, Saltó C, Vennström B, Reh TA, Forrest D (2001) A thyroid hormone receptor that is required for the development of green cone photoreceptors. Nat Genet 27:94-98.

Ng L, Goodyear RJ, Woods CA, Schneider MJ, Diamond E, Richardson GP, Kelley MW, Germain DL, Galton VA, Forrest D (2004) Hearing loss and retarded cochlear development in mice lacking type 2 iodothyronine deiodinase. Proc Natl Acad Sci U S A 101:3474-3479.

Ng L, Ma M, Curran T, Forrest D (2009a) Developmental expression of thyroid hormone receptor beta2 protein in cone photoreceptors in the mouse. Neuroreport 20:627-631.

Ng L, Hernandez A, He W, Ren T, Srinivas M, Ma M, Galton VA, St Germain DL, Forrest D (2009b) A protective role for type 3 deiodinase, a thyroid hormone-inactivating enzyme, in cochlear development and auditory function. Endocrinology 150:1952-1960.

Nikonov SS, Kholodenko R, Lem J, Pugh EN Jr (2006) Physiological features of the $\mathrm{S}$ - and $\mathrm{M}$-cone photoreceptors of wild-type mice from singlecell recordings. J Gen Physiol 127:359-374.

Nikonov SS, Brown BM, Davis JA, Zuniga FI, Bragin A, Pugh EN Jr, Craft CM (2008) Mouse cones require an arrestin for normal inactivation of phototransduction. Neuron 59:462-474.

Pepperberg DR, Cornwall MC, Kahlert M, Hofmann KP, Jin J, Jones GJ, Ripps H (1992) Light-dependent delay in the falling phase of the retinal rod photoresponse. Vis Neurosci 8:9-18.

Plate EM, Adams BA, Allison WT, Martens G, Hawryshyn CW, Eales JG (2002) The effects of thyroxine or a GnRH analogue on thyroid hormone deiodination in the olfactory epithelium and retina of rainbow trout, Oncorhynchus mykiss, and sockeye salmon, Oncorhynchus nerka. Gen Comp Endocrinol 127:59-65.

Pugh EN Jr, Lamb TD (1993) Amplification and kinetics of the activation steps in phototransduction. Biochim Biophys Acta 1141:111-149.

Rich KA, Zhan Y, Blanks JC (1997) Migration and synaptogenesis of cone photoreceptors in the developing mouse retina. J Comp Neurol 388:47-63.

Roberts MR, Srinivas M, Forrest D, Morreale de Escobar G, Reh TA (2006) Making the gradient: thyroid hormone regulates cone opsin expression in the developing mouse retina. Proc Natl Acad Sci U S A 103:6218-6223.

Rovet J, Daneman D (2003) Congenital hypothyroidism: a review of current diagnostic and treatment practices in relation to neuropsychologic outcome. Paediatr Drugs 5:141-149.

Shibusawa N, Hashimoto K, Nikrodhanond AA, Liberman MC, Applebury 
ML, Liao XH, Robbins JT, Refetoff S, Cohen RN, Wondisford FE (2003) Thyroid hormone action in the absence of thyroid hormone receptor DNA-binding in vivo. J Clin Invest 112:588-597.

St Germain DL, Hernandez A, Schneider MJ, Galton VA (2005) Insights into the role of deiodinases from studies of genetically modified animals. Thyroid 15:905-916.

Strettoi E, Mears AJ, Swaroop A (2004) Recruitment of the rod pathway by cones in the absence of rods. J Neurosci 24:7576-7582.

Szél A, Röhlich P, Mieziewska K, Aguirre G, van Veen T (1993) Spatial and temporal differences between the expression of short- and middle-wave sensitive cone pigments in the mouse retina: a developmental study. J Comp Neurol 331:564-577.

Trimarchi JM, Harpavat S, Billings NA, Cepko CL (2008) Thyroid hormone components are expressed in three sequential waves during development of the chick retina. BMC Dev Biol 8:101.
Visser WE, Friesema EC, Jansen J, Visser TJ (2008) Thyroid hormone transport in and out of cells. Trends Endocrinol Metab 19:50-56.

Wiszniewski W, Lewis RA, Lupski JR (2007) Achromatopsia: the CNGB3 p.T383fsX mutation results from a founder effect and is responsible for the visual phenotype in the original report of uniparental disomy 14 . Hum Genet 121:433-439.

Xiao M, Hendrickson A (2000) Spatial and temporal expression of short, long/medium, or both opsins in human fetal cones. J Comp Neurol 425:545-559.

Xu XL, Fang Y, Lee TC, Forrest D, Gregory-Evans C, Almeida D, Liu A, Jhanwar SC, Abramson DH, Cobrinik D (2009) Retinoblastoma has properties of a cone precursor tumor and depends upon cone-specific MDM2 signaling. Cell 137:1018-1031.

Young RW (1984) Cell death during differentiation of the retina in the mouse. J Comp Neurol 229:362-373. 